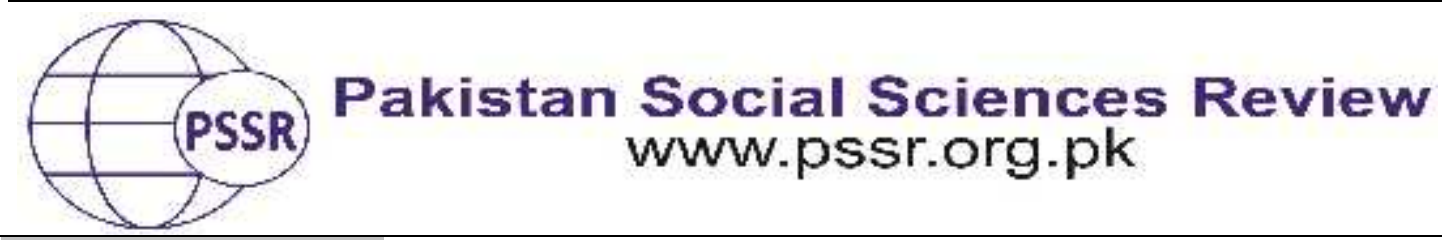

RESEARCH PAPER

\title{
Legalizing Hijras (Transgenders) in Patriarchy: Barriers in Legal Registration of Hijras in Punjab, Pakistan
}

\author{
Umair Ahmed ${ }^{1}$ Prof. Dr. Ghulam Yasin ${ }^{2}$
}

1. Lecturer \& PhD. Scholar, Department of Sociology \& Criminology, University of Sargodha, Punjab, Pakistan

2. Professor, Department of Sociology \& Criminology, University of Sargodha, Punjab, Pakistan

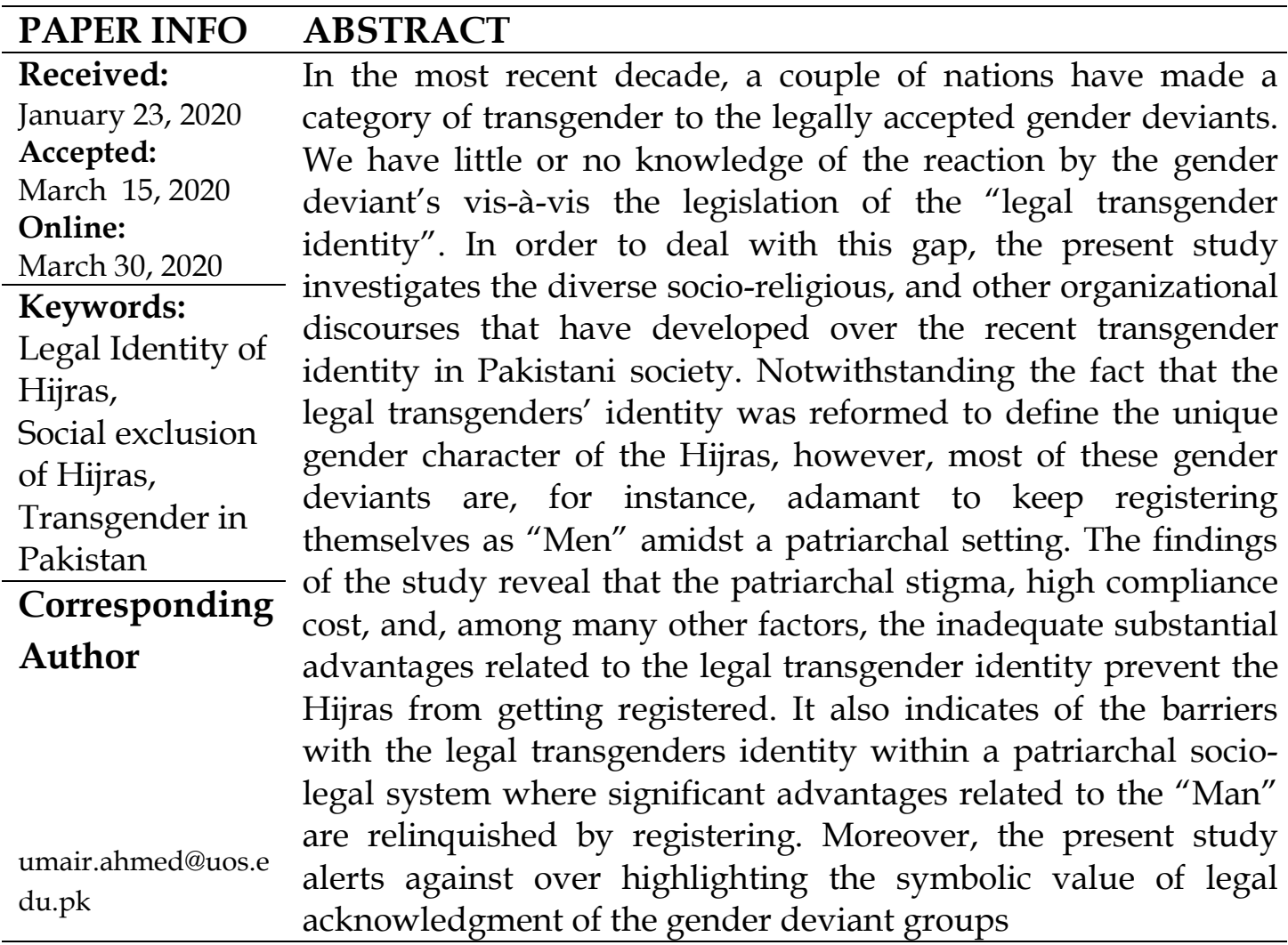

\section{Introduction}

Recently, few nations especially in the South Asian region like Pakistan, India and Bangladesh have decided to make a legal transgender category to legally acknowledge those who don't attribute to the dual gender identifications. Yanow (2003) noted that the previous studies indicated the barriers in the national identification policy and, the issues innate in constraining the personality of gender deviants to the dual gendered legitimate framework (Monro 2005; Spade 2008; Salamon 2010) and (replace with "as well as,") the dynamics of legal articulation of the transgender (Bochenek and Knight 2012; Knight, Flores, and Nezhad 2015). 
Moreover, very few studies have been conducted especially on the instrumental and symbolic values of the legal transgender identity for gender deviants. Furthermore, the researchers (Stryker, 2004: Dufner, 2015) highlight the significant issues related to the construction of a transgender category for the persons who do not fall in the defined spheres of the dual gender categories. It can be safely contended that no, or very inadequate, research studies have been conducted to explore the attitudes of the gender deviants towards their legal transgender identity. Hull (2016) also indicated another gap in past studies i.e. the little understanding of the various manners through which the distinct discourses and social organizations influence the gender deviants experience within a patriarchal legal structure, particularly in non-western social settings.

In order to deal with these significant gaps in the study on legal identity as well as legal consciousness of gender deviants, the present study investigates few research questions: First, how do gender deviants understand and react to the legislation of their transgender identity? Second, what are the discourses like social, religious and other organizations that affect the legal consciousness of Hijrasvis-a-vis legitimate transgender identity? Finally, the study mainly addresses Hijras as a socially excluded gender deviant group in Pakistan. The present study also examines the diverse social discourses that established right after the verdict by Supreme Court of Pakistan, calling for legislation covering the legal identity of Hijras and also, studies the effects of the court verdict on the ensuing legal consciousness among the Hijra community.

The study also highlights the barriers in the process of legal transgender identity in a patriarchal socio-legal structure, where significant advantages related to legal "Man" must be surrendered while opting to be legally recognized as a transgender. The outcomes of the study propose that various gender deviants opt the legal gender after undergoing the cost benefit analysis of the socio-legal advantages of being legal transgender against its opportunity cost. Consequently, proclaiming the legal transgender identity is not, generally, the irrefutable decision for gender deviants. While undergoing this research venture, I could easily make out that the Hijras deal with a "patriarchal bargain" (described by Kandiyotiin 1988) and prefer the identity of being a legal "Man" because many socio-economic and legal benefits are associated with this identity, given the patriarchal setup of our society. Moreover, the present study recommends that meanwhile, the legal transgender challenges the neutrality of the dual-gender structure-a significant organizational base of male dominated society. Custer (2016)also mentioned that various patriarchal organizations (like family and other formal institutions) involve to discourage Hijras from getting the identity of legal transgender. Consequently, established patriarchal structure, in its different forms, appears as a significant arbitrator of the legal consciousness of gender deviants. Generally, the study suggests that without having accompanied by material advantages to counterbalance the established patriarchal prejudices against it, the legal transgender is not, perhaps, a workable policy for social inclusion of gender deviants. This is 
particularly vindicated in areas like South Asia where such persons mainly extremely marginalized. Moreover, the present research recommends that owing to the specific psycho-social and, monetary disadvantages, considering a legal transgender identity may potentially worsen the socio-economic condition of the gender deviants.

\section{Legal Consciousness of Hijras (Transgender) in Pakistan}

Worldwide, the legal acknowledgment of gender deviants endures a significant uncertain policy, as no solitary methodology exists to legally contain the distinctive identity of the people facing gender based social exclusion (Butler 2004). Whereas, according to Schilt, and Westbrook (2009) few nations permit change in legal gender, normally depend on evidencing physical reconfiguration of body by medical surgeries, these strategies have been condemned for trying to include the distinctive characters of gender deviants within the dual-gender structure. Fraser (2001) also noted that in the last decade, a few nations have decided to legally recognize the gender deviants or intersex people by making a new gender category. This step reflects a remarkable policy shift towards the legal acknowledgment of gender deviants. But historical facts revealed that there have been very unsatisfactory results of legal recognition policies of these minorities.

The study of Legal consciousness is "the search for the forms of participation and interpretation through which actors construct, sustain, reproduce, or amend the circulating (contested or hegemonic) structures of meanings concerning law". Silbey (2005) further describes it as the inadequate social impact of legal acknowledgment. The Legal conscious analysts demonstrated that the citizen-law association is dependent upon the social discourses and organizations in which the law performs. Similar in the existence of apparently universal laws, their discrepancy assessment through "intermediating features e.g social networks, interactions with legal actors, the media; and individual factors including familial desires and demographic and socioeconomic characteristics" (Baumle and Compton 2015) is a significant factor of how people react to the legal acknowledgment of their identities. In this manner, Ewick and Silbey (1998) noted that legal conscious study investigates the significant difference between law and legality i.e. meanings, origins of authority, and cultural practices which are generally acknowledged as legal. To exemplify, in our daily lives "welfare stigma" (the term used by Moffitt, 1983) where number of competent people won't take on government welfare schemes due to prejudice and stereotypic image of welfare beneficiaries (Stubera and Schlesinger 2006). In the current scenario, are the significant factors that confuses the legality of the legal transgender identity are the established patriarchal society, the arrangement of social constructions, discourses, and practices through which unequal power relations among men and non-men are existing. According to Custer (2016), "rigid belief to a dual gender structure is essential for supporting patriarchy. Contrarily, the gender deviancy contests the dual structure and henceforth the patriarchal status quo."In keeping with this potent threat, Walby (1990) argued that different patriarchal organizational orders, e.g. family, and government, attempts to ensure that the 
gender deviants are brought in congruence with the socially characterized gender identities. Formation of legal transgender identity is probably going to overemphasize "gender panic" in male dominated organizations to ensure the category doesn't turn into a feasible choice for gender non-conforming people (Westbrook and Schilt 2014).

The investigator on legal consciousness (Silbey2001), has enlightened the hidden elements of the various manners by which individuals "engage, avoid, or resist the law and [its associated] meanings". There are basic procedures in the law by which people react to the law: "Before the law, with the law, and against the law". First, "Before the law consciousness" considers law as instrumental, unbiased, authoritative, and beyond the social setting. In such consciousness, there is little space for personal action, as law is supposed to describe course of action and legal conduct. Secondly, with the law consciousness study "legality emerges as aground in which actors fight to attain variety of purposes - individuals also know that there are disadvantages related with using the law, or using it in a definite way. Understanding these limitations on legality - citizens usually choose to turn to the law, or confront the law, only after a rough reckoning of the likelihood of understanding the ends sought". Lastly, "against the law consciousness" considers the law as "something to be avoided" and "legality is seen as capricious and, thus, dangerous to invoke". It embraces distinctive means in which persons deal with the capacity and authority of the law by opposing its obligatory connotations and characters (Ewick and Silbey, 1998).

Silbey (2005) also described that there has been a distinct effect of legal consciousness research on the legitimacy of socially excluded communities, as to know how legitimate identity of socially excluded communities' effecton their legal consciousness. Conversely, Hull (2016) noted that the legal understanding of lesbian, gay, bisexual and transgender (LGBT) groups keep on staying a generally disregarded standpoint where the inadequate past studies have essentially, and arguably, focused on parenting styles (Connolly 2002; Baumle and Compton 2015) plus conjugal problems described by Hull 2003; Harding 2006, 2011; Richman 2014). The present study pointed out the difficult heterogeneities in how LGBT people react to a confused and inadequate socio-legal manner. Nevertheless, inadequate past researches have concentrated on the legal awareness of gender non-conforming people. For example, as to Hull (2016), it is a significant constraint as gender deviants" face legal difficulties and barriers that are slightly different from the concerns of sexually biased minorities, [for example] contests about legal procedures of gender recognitions". As Inoguchi and Blondel (2010) describe that studies of legal consciousness on LGBT people have been initially conducted in western nations. Meanwhile state and law are attributed with many senses in other parts of the world, we still have restricted context-specific perception of the various manners in which gender deviants understand and react to their legal identities.

\section{Socio-Legal Status of Hijras (Transgender) in Pakistan}


In Pakistan, Hijra community is a diverse group which comprises a great number of gender deviants. Mostly persons from the Hijra community are naturally males but have feminine gender preferences, various male-to-female transsexuals, intersex, and inept people, and victims of child sexual abuse are likewise selfdistinguished as "Khawaja Sira". But, approximately every individual, nonetheless of their motives for joining, accept the female gender after joining the Hijra community. In a general public that has one of the most significant digits of missing women and exceptional benefit is associated to the male child, the main sin of the Hijras who are commonly labeled as "son" in their birth to the world is their request that they are "not men." (Khan 2007; Sen 1992). By their feminine behavior, the Hijras confused not simply the instinctive nature of a dual gender framework and additionally, the denouncement of the social roles expected from or attached to men. Ahmed 2014 argues that mostly Hijras are thrown out from their homes, in early adolescent age, normally after rehashed verbal and physical abuses. After departing their homes, such people normally join the Hijra community and, in view of a complex family relationship system become "Chela"(Student or Child) of a "Guru" (Guardian or Teacher). Due to the humiliation from the society and especially from their own families, very small numbers of Hijras are educated. Some of them, who joined schools, usually left their education because of the variety of humiliating attempts and sexual victimization. Due to social exclusion, many Hijrasas being their socially written fate are not offered a decent livelihood, Resultantly, they earn their livelihood through variety of socially unacceptable services to include; begging, dancing at weddings, shrines, local parties and prostitution to make their livelihoods. Over all, the Hijras are considered to be the outcast category in Pakistan and had no Legal cover of human rights until recently.

A night of 2009, some Hijras were arrested by the local police, while they were dancing at a wedding function and later on reported violent treatment at police custody, Meanwhile an advocate appealed in the Supreme Court to make sure, the Hijras ("Khawaja Sira community" the word She-males was used in the appeal) should be given their basic human rights In light of the Constitution of Pakistan. The leader of the Pakistan She-Male association, Almas Boby, additionally joined the case as petitioner in-attendance. The Supreme Court (SC) gave various orders, from2009 to 2011,During various hearings of the case regarding the social status and legal identification of the Hijras in Pakistan. The most important development after this case was the legislation of "transgender identity" to legally acknowledge the distinctive identity of Hijras in Pakistan. In its last verdict, the SC announced that the "rights including right to life and dignity of the (Khawaja Sira community) are equally protected (by the constitution). Thus, no discrimination, for any reason, is permissible to the extent that their rights and obligations are concerned." where the SCof Pakistan verdict had its constraint particularly in its verbalization of the "transgender identity" as being biological base, it was generally recognized as an optimistic movement towards the social inclusion of the Hijras. 
In light of the verdict of the SC, the National Data Base and Registration Authority (NADRA), a governmental organization which provide the legal Identifications (known as "Computerized National Identity Cards or basically CNIC") introduced a new gender category for Hijras, formally known as "Khawaja Sira", in the system of its national registration. Whereas this verdict to make the legal category of transgender identity was escorted with detail elaboration, the reaction of the Hijras to this new gender identity has been disappointing. According to "The News" (2015) report, just 1432 people had picked the legal transgender. While Baig (2012) noted that the evaluated digit of the Hijras in Pakistan ranges from 80 thousand to 300 hundred thousand, this figure shows that under 2 percent individuals from Hijras have Availed the legal transgender identity. This illogical decision apparently confused the contributory and emblematic values of the legal transgender identity. Accordingly, this study is conducted to know how the Hijras understands the legal transgender identity and the diverse social discourses that impact the legalization of the transgender in Pakistani society.

\section{Material and Methods}

The data of present study was collected during a nine-month ethnographic research in the target population of three big cities i.e Lahore, Rawalpindi and Multan of Punjab province, Pakistan. Moreover, the direct and participant observation, and in-depth interviews were conducted with 50 Hijras to understand their experiences, personal and social options and priorities. The Ethnography research in present study is based on the notion of Levy and Hollan (2014) "intersubjectively" which creates social domain and allows the investigator to placea person innumerous social, symbolic, and material discourses. It leads the path of selection to inquire into diverse features of legitimacy, subjectivity, and action. In order to get basic information of Hijras and their community, the key informant was used to access the Hijra community, who also assisted me and became acquainted with their special language "Farsi" utilized for private correspondence inside their community.

Infield work, I went to many locations to meet the resident Hijras in order to conduct interviews, I arranged 74formal meetings with 50 Hijras at 15different locations. Of these, five were Hijra "Deras" (place commonly possessed or leased by the Guru where different individuals from the Hijras community live respectively), four were occupational areas, and were residents of Hijras. For the present study, I interviewed many Hijra respondents, with distinctive ages, education and professions, from different angles.

Table 1

Demographic Characteristics of the Respondents

\begin{tabular}{cc}
\hline Age & No \\
\hline $18-30$ & 8 \\
\hline $31-40$ & 11 \\
\hline
\end{tabular}




\begin{tabular}{cc}
\hline $41-50$ & 15 \\
\hline $51-60$ & 13 \\
\hline Above 60 & 3 \\
\hline Total & $\mathbf{5 0}$ \\
\hline Education & 26 \\
\hline Illiterate & 3 \\
\hline Informal/Madrassa (Religious education) & 16 \\
\hline Formal primary education/ schooling & 2 \\
\hline Secondary School & 3 \\
\hline College/University Graduate & $\mathbf{5 0}$ \\
\hline Total & \\
\hline Wants to get legal gender identity (Total \\
Respondents N=50) & 38 \\
\hline Man & 11 \\
\hline Khawaja Sira & 1 \\
\hline Don't want & \\
\hline Wants to get legal gender identity \\
(Respondents with IDs $\boldsymbol{n}=\mathbf{1 8 )}$
\end{tabular}

The data was collected and coded in the local languages of research respondents like Urdu and Punjabi (and Farsi). The collected data was coded by following the Kuckartz (2014) thematic analysis procedure by using the software MAXQDA. After successfully conducted some initial interviews, the data was coded to categorize main themes and then utilized the initial investigation to advise upcoming meetings. The unit of analysis was the person or individual subjects in order to investigate the heterogeneity of research respondents, and the main focus of the study was the legal consciousness of the Hijras. In order to secure the dignity of my research respondents, I have utilized their pseudonyms in the discussion sections.

During the fieldwork, several checks for trustworthiness (e.g., reflexive sectioning, respondent approval or representing self) were used for subjective interpretive research in order to experiences of my research respondents. Significant justification in this regard, my position was a cisgender man. Cisgender man usually employ in gender monitoring of the Hijras more often as compared to cisgender women. Besides, as most individuals from the Hijra community are inclined towards males as sexual partner, they also attract many unwelcome descorts. My status as a married person with children was useful in the field work because in the prevalent 
culture of Pakistani society, being an unmarried male has different position and social construction when contrasted with someone who has kids. I experienced that this feature was very beneficial for me in discouraging some early fearfulness that my research respondents had about the experience of male researchers. Some Hijras were frightened with mostly male journalists and research scholars who scandalized their information which they were given to them. The permission letter in this regard was also helpful for me because I could not breach a code of conduct such as ethics, confidentiality and privacy that appeared to address some of the primary concerns of my respondents. While many journalists have a temporary engagement with the Hijras community for their news article, it was my long-term engagement with Hijra community that helped me earned their trust.

\section{Legal Gender Identity of Hijras in Patriarchal Discourses}

\section{Legal Transgender Identity in Family Discourse}

The government issued new Identity card in the name of our Gurus but we need our biological parents' names on this new identity cards because they brought us in this world, our mother kept us nine months in her uterus, our father took care for us in our childhood and did hard work. How government can easily erase their name on our new identity cards? (Kajool 34, Jobless, Chela)

The three Khawaja Sira (Hijras) came to my home some days before. They were looking like women and even they had done sex realignment. They asked me "sister we need to get the new legal identity as "Man" I replied, but why not register as Khawaja Sira because you look simply like women. So, they answered, "No Sister not at all! Our family members and relatives will kill us if we do that" ... I think less family pressure will encourage more among us may register as Khawaja Sira. (Saima, 47, jobless, a compelling Guru)

The aforementioned narratives could be interpreted in different manner through which the impact of family on their legal consciousness could be seen. Various families experience the individuals from the Hijras and effectively dishearten an open presentation of their womanlike character considerably after they are kept in or tossed separately from their residences. Such as, a respondent noted that she was severely tortured by male members of her biological family when her interview was broadcasted on a news channel of National television regarding the privileges of the Hijras, because she was mentioned to have received disgrace on her family. Another respondent said that she was taken to her biological family by a fake SMS and they trimmed her long hairs and cut her nails forcibly to limit her feminine identity. The series of this an anxiety vis-à-vis on the honor and reputation of families come at its apex when they come to know by their personal sources that their "male Child" is going to legally get registered as "Khawaja Sira". Therefore, different tactics, such as threats of violence, humiliation, or even to be murdered and refused to give family verification (which is compulsory for getting legal 
registration)are resorted to deter the members of family from opting the legal identity as transgender.

Nevertheless, the impact of family on the legal conscious of the Hijras isn't generally as outer intimidation. As noted in the context of welfare stigma, persons frequently assume stereotypes related with being a welfare beneficiary. This disguise, thusly, brings about refusal to take an interest in government welfare programs No matter whether if one is qualified to get the advantages (Stubera and Schlesinger, 2006). A large number of the research respondents had equally disguised the social discourse that opting the identity of legal transgender implied disowning by their biological families. This was somewhat in light of the fact that most individuals from the Hijra community accept that a vital piece of picking the legal transgender is to supplant their dad's name with that of their Guru despite the fact that this is legally impractical. That is the reason most Hijras demand the ID of the legal "Man" as the family card and other with the transgender as the "Khawaja Sira card".

Despite the fact that mostly Hijras had been forced to leave their biological families, having formally disowned from their biological family remained a taboo as compliance to biological parents and emotional association with the family are worshiped in Pakistan (Stewart et al. 2003). For Hijras, it seemed as if opting legal identity as transgender, would make their breakup from "real" or "biological family" and they finally opted the legal identity as "Man" As they thought they would, to get the least, be symbolically associated symbolically associated with their biological parents. Rema, a 56-year-old research respondent, sum up this feeling the best when she told, "There is no need of legal identity as a transgender. People say get it, get it. How can one forget one's family, one's parents?" Amongst the respondents of the present study, only those who had faced mainly worst breakup from their biological families, or whose parents had passed away, desired to opt the identity of legal transgender. Furthermore, arguably some of my respondents, even some of my respondents demanded that the state should permit them to mention their "Guru's" name in its place of their biological fathers to let them formally breakup from biological families.

\section{Legal Transgender identity and Religious Discourse:}

In Pakistani society, religion has a significant role in shaping the governance system, where people feel honor in being constituted as an Islamic state. That's why the religious scholars have very strong Influence in shaping public opinion on various matters. However, the various sources of Islamic Laws are also silent, or unexplored, regarding the identity and discourse of Hijras. Many contemporary religious scholars in Pakistan depend on the predominant social constructions in the society that is impossible for gender-sex disjunction and the only "real" Hijra is congenital and naturally determined. These scholars have firm belief that, Hijras are men and act as women, so they should act according to their religious obligations only as normal or real men. 
Ironically, while these social discourses are challenged by many Hijras because these discourses consider their feminine behavior or feminineness to be illegal; when it comes to religion, they have to obey the rules of pre-dominant social discourses which strongly support patriarchy. Mostly Hijras admit the religious discourse that they are naturally men and must perform all religious practices like men otherwise, those practices will remain flawed. According to Reema's opinion "In our parents' homes, we are inborn as "Boy" we will be resuscitated with male body at the day of judgment and that she desires to be standing in the Prophet's row (implying the row of men) on the day of judgment,". These views were the generally constant regarding the religious believes among Hijras. It is astonishing because many of other opinions of the Hijras regarding their self-identification depend on the notion that the feminine soul has been trapped in their masculine body. Being a researcher, I would have understood that religion should not be problem with the body of an individual but with his soul. However, in religious discourse, the body takes over and the soul ironically takes a back seat for the Hijras.

These religious beliefs of Hijras become very significant while traveling to Saudi Arabia for performing religious practices i.e. "Umrah or Hajj" (religious journey). Mostly Hijras accept, they will also not be permitted to enter in Saudi Arabia to perform religious customs like women if they opt the legal identity of transgender. To them, these two options are inadmissible. The respondents of the present study revealed different narratives where their Hijra companions were not permitted to make a trip to Saudi Arabia. Rao (2016) reported that these feelings of anxiety were increased when various news outlets announced that Saudi Arabia had prohibited all the Hijras from traveling to the state. While according to Wall Street Journal (2016) that news was denied very soon by authorities from the embassy of Saudi Arabia in Islamabad, the Hijras are still worried about opting the legal identity of transgender or traveling internationally wearing ladies' outfits. As one respondent said, "Khawaja Sira cannot go for Umrah. Khawaja Sira who has long hair and nails with bosoms can't go for Umrah either even they register themselves as men. Some Hijras went to Umrah [in late months] yet they trim their hair short and every one of them had ID as men." it is generally easy for the Hijras to go to Saudi Arabia as "Men" as there is no legal framework that restricts their traveling. The ambiguities in this regard in making a trip to Saudi Arabia feature the characteristic trouble in presenting legal transgender in the international administration setting. Even if Pakistan legalizes transgender people, they all must obey with the dual gender construction as traveling to abroad.

\section{Costs-Benefits of Legal Transgender Identity for Hijras}

For many Hijras, the option of being a legal "Man" also is provoked by more practical issues. There are many monetary benefits related with a "legal masculine identity" in a patriarchal socio-legal system, so one must give up choosing the legal transgender identity. Like, according to Islamic and Pakistani law being a man has maximum share in heritance rights than women. Mostly Hijras suppose, by opting 
the identity of legal transgender, they would not be permitted to get the inheritance right of men and will instead obtain the inheritance of women. Nida (42, unemployed, an activist of Khawaja Sira rights) revealed that:

I generally state that we must register as legal "Men" otherwise we will be considered women and substitute of getting a higher (12 anay) share (equal to a man) we will be given a little (4 anay) share in inheritance as they (our brothers) would state that since we registered as Khawaja Sira, we are currently equivalent to sisters. That is the reason I encourage everybody (in the Hijra community) to get IDs as men ... to guarantee total [and due] share in inheritance.

The above narratives relating with the identity of legal transgender and a little share of heritance rights widely among the Hijras and generate strong outcomes just like Nida, some other respondents also stated heritance right as one of the main causes behind why they legally register as men. In various cases, their main issue was not regarding what their rights were in inheritance, but whether if they got any right at all. While, according to the verdict of SC of Pakistan, Hijras are usually deprived of any right in their family heritance or property and this deprivation is normally justified on the basis that they do not have any spouse or kids so they don't need to save or care for anyone else. Such as, one respondent of the study asked her father why he eliminates her from his will? he replied doubtfully, "What use would you have for the property?" Legally register as "Men" is a ray of hope for Hijras, who legally recognize themselves as "Men", to help convince their parents or siblings as to let them get their proper right in family inheritance or property.

Whereas there are significant advantages of heaving registration as legal "Men", there are very minimum benefits related with the identity of legal transgender. Although the government had taken the important steps for socioeconomic benefits of the Hijras by the direction of Supreme Court of Pakistan e.g., employments and educational opportunities etc. but, unfortunately, none of them have been implemented. Additionally, mostly institutions in Pakistan have various strategies for the collecting of gender associated evidence, not any of which relate any substantial advantages associated to the identity of legal transgender. For example, Shabnum (39, employed) revealed:

What benefit of legal transgender? for us except that the "transgender" is added to all forms, for example, related to transfer of property, variety of certificates, on forms for admissions in education institutes. In all such legal documents, there is no option of the third gender but, to mention either Man or Woman. Unless a third category is added all over, how can we get our due Recognition and dignity (izzat).

A comprehensible example of this disjunction is, when in 2012 NADRA announced jobs for the Hijras, instead of considering transgender on legal ID card as an evidence of being a "Khawaja Sira", it demanded for a medical evidence for proving that the candidates were real or inborn "Khawaja Sira". Therefore, it was legally possible for a person to be registered as a "Man" and can apply for the job as 
a "Khawaja Sira" (which was the opportunity taken by many candidates). On the other hand, those who registered legally with the identity of transgender could not avail that opportunity without medical certificate which can verify their inborn Transgender characteristics. Likewise, some local NGOs that work on many social welfare programs for the Hijras, do not need the legal identification of Hijras for enrollment in their programs. Instead, these NGOs prefer unofficial verification by other Hijras of their community or they can give self-verification.

In Pakistani society, it is significant to note that there are only two genderbased prongs through which the vacancies are reserved only for men and women in many public organizations like schools, hospitals, banks etc. Although a legal category of transgender has been declared but No changes have been made in the legal frameworks of different government and private institution to specify job opportunities for Hijras. Surprisingly, no segregated queue exists for the Hijras even in the NADRA offices, and thus, Hijras must line up with either men or women to apply for legal registration or IDs. As Rasham (26, jobless) explains:

There is no segregated line for us. When we are wearing feminine outfits, we stand in the women's line and when we have masculine dressing, we stand with men. While the men start teasing us the women start laughing at us.

In the last, it is also significant to mention that some Hijras prefer the identity of legal transgender due to its emblematic benefits. Whereas, they were very few numbers of Hijras with whom I met, they generally used the word "Pehchaan" (Urdu/Punjabi language word) meaning, recognition or identity to convey the significance of the identity of legal transgender. This newly constructed gender category by state, provides Hijras an independent or distinctive legal "Pehchaan" which offers the legality to their identity. Likewise, very few respondents of the present study considered the identity of legal transgender as being very useful in segregation between real and fake Hijras. Where the society treats inborn Hijra as real, for the Hijras, genuineness is identical with completely adopting their way of life. Mostly, Hijras are worried about those men who act same like them by wearing outfit of women and putting on makeup to beg at traffic signals, but live as men in their private life. This is because they are indirect context for charity, these men are seen as "usurping the rights" of Hijras. The identity of legal transgender, offers a chance for Hijras to expose such outcasts as fake. Komal (55, jobless) described:

We state that Hijras should be registered so that those Khawaja Sira with Legal IDs can be documented as "authentic" and unauthentic Khawaja Sira - who are married with have wives and children yet wear women outfits like us to beg in our place - can be exposed and detached from our crease.

\section{Legal gender identity and Administration Cost}

Administrative Cost is another aspect that discourage the Hijra community from opting the legal transgender identity. Moynihan, Herd, and Harvey (2014) 
claimed that in order to get legal IDs or registration, Hijras face the high learning, compliance, psychological and Administrative costs. They also experienced a high administrative cost while applying for legal IDs because of their social marginalization. On the other hand, these administrative costs amplify disproportionately for some Hijras who were formerly legal "Men" but eventually somehow want to opt the identity of legal transgender. These candidates are mandatory to show medical certificate for proving their inborn transgender identity. While many members of the Hijra community are naturally or inborn real males who choose to register as women, they cannot fulfill this prerequisite and are forced to register as men. The Hijras face a higher administrative cost in the form of time and transportation cost in getting medical verification certificates from entitled government hospitals in order to verify their "transgender status". In order to obtain the necessary documentation, these individuals are harassed and ridiculed in these hospitals, which make it challenging for them to navigate the bureaucratic policies.

Furthermore, according to the government policy, no medical certificate is necessary to acquire the legal transgender identity for those who do not have a previous ID. Though, even in this case, lack of understanding both among the frontline officials of NADRA and the Hijras about legal gender management policies pushes the Hijras to fulfill with unneeded certification requirements. The under mentioned argument of Kiran (43, the activist of Khawaja Sira rights) whose friend Nargis desired to opt the identity of legal transgender isan example:

In NADRA office, we had a long argumentation with the officers. They told us they couldn't help us in the registration as legal Khawaja Sira unless we submit medical documents which will verify the veracity of our gender status as Khawaja Sira. When we (Rasham and Nargis) Reached Meo hospital Lahore for medical certification the next day, the frontline medical staff informed us that we were too late and to come again the next day. The Next day, when we reached the hospital again, they told us that the they (the hospital authorities) are not authorized to issue such medical certificates. Only Services and Munshi Hospitals can issue these certificates according to Govt. policy. After that, I thought enough is enough and told Neeli to go home.

The intense documentation is one of the multiple barriers to discourage the Hijras from selecting the legal transgender Identity, while it is also difficult to register as a legal "Man" however mostly frontline officials also openly encourages this option as it follows the pre-dominant socio-religious constructions regarding the Hijras. As Anmoal (59, jobless) revealed that:

We have experienced so many barriers in getting registered as a "Khawaja Sira". [The frontline Officals say that] you should have mustaches or beard. If you want to go to Sudia Arabia to perform Umrah, you should have legally registered as a man. You don't look like a woman.

And Almas (37, jobless) stated that: 
The frontline staff of NADRA sent me back 4 times when I went there for Legal ID because they know me and my biological family. They said that why you disown your parents by by registering as a Khawaja Sira even they are still alive as we know? We all know you and your family background. It would be difficult for us to write your name as Khawaja Sira on Legal ID... You should not disown the name pf your parents.

Another understated but important, feature of legal identification of Hijras is linked to the option of terminology in legal policy. The word "gender" used in legal registration policy of NADRA although the social scientists can batter differentiates between gender and sex, which is not known to many Hijras. On the other hand, to explain their self-identity, they suggest the difference between body and soul. Most of the research respondents stated that they had men-like bodies with women souls. If the category of "soul" was used instead of gender on the legal ID, most of the Hijras would have picked the legal identity of women gender.

\section{Conclusion}

The challenges for the Legal consciousness scholars are the domination of existing law in its capacity to describe and present the formally authorized identification as legal and instrumental. Though, not all identities are formed uniformly; the socio-legal advantages and disadvantages related to distinctive formal identities symbolize the legally prescribed status of the persons presuming those identities. This implies that the introduction of a legal third gender represents a position in the socio-legal framework being offered to the Khawaja Sira community by the state obtaining the identity of legal transgender means, Hijras accept the discourses and outcomes related with this new identification which was legally created. This study indicates several organizational and rambling aspects which effect, and restrict, the legitimacy of the transgender identity for the Hijras. Therefore, Hijra community is reluctant to choose the legal transgender identity.

The legal consciousness can be described as the law consciousness of Hijras, because they deliberately get their identity as legal transgender to obtain material rewards, social and religious rights related with being a legal "Man". For example, Harding (2011)a legal pluralist purpose that

"The term law is conceptualized too narrow and if we incorporate normative social structures such as family and religion within our definition of law, the Hijras really shows in front of the law consciousness as they conform to the patriarchal socio-legal order to reify the dual-gender structure by registering as men". Although being a researcher, it can be stated that this option of the Hijras do support a few patriarchal socio-religious discourses regarding them, it is important to remember that the Hijras oppose the similar discourses when they face in their daily life, commonly at high personal or exclusive cost. Why, when it comes to the selection of their legal transgender identity, do they conform these organizational discourses? Being a researcher, I argue that this selection of the Hijra community challenges the 
domination of law which is based on patriarchy in many ways, as well as the legal consciousness of Hijras should be conceptualized as a calculated "patriarchal bargain" based on their own cost-benefit analysis (Kandiyoti, 1988). There are most important features of this negotiation which are as follows:

Firstly, the study reveals that many Hijras do not acknowledge the Process of judging of their self-identity in legal system. Before starting the data collection process in the present study, I thought that the initiative of legal transgender identity by the state would be very important for the Hijras due to its symbolic advantages of their transgender status. But very soon I realized, that there is no respectable place, or the workplace for Hijras in our society. The notion of concealing their identities or not legally choosing their identities is enough for other genders to marginalize them and exclude them from their social or legal recognition as a third gender for mostly Hijras. If they register as "men", It will prevent them from living their lives as transgenders. Even if they opt the identity of legal transgender, the mass opinion in the society is unlikely to change because our patriarchal society already blames them to be fakes. Therefore, in order to get the personal benefits, most of the gender deviants decide to advantageously use the pre-dominant patriarchal legal structure.

Secondly this study highlights a very significant point is the lacking of material advantages related with the identity of legal transgender for Hijras. Mostly Hijras may want choose the legal transgender after calculating its maximum benefits, if they get material benefits like social welfare to Hijras for their legal transgender identity by the State. For example, generally the state distributes funds to various groups on the base of their population, but the state is reluctant to give any financial or material benefit to those with the identity of legal transgender because they are very few in number i.e as according to Dawn 2015, a minister in Punjab province, said that the government was unable to announce any quota for the Hijras as officially registered Hijras were very small in numbers. Therefore, there is no suitable option for the Hijras after the verdict of SC of Pakistan because the opting of the legal transgender identity means, Hijras will have to bear the socioreligious stigma and while opting for registration as legal "Men" means they will have to sacrifice futuristic plan of their social inclusion because the special benefits are related with the masculine personality,.

It is important to know the difference between "Strategic" and "Practical" gender interests. Such as mostly Hijras in Pakistan live in very extreme margin in the "practical interests" (especially material and religious) that are more urgent and essential for legal "Men" (Molyneux's, 1985). Instead, there is no surety that their "strategic gender interests" (such as socio-economic inclusion) will be given by opting the identity of legal transgender even at least short term. So, Hijras makes a purposeful "Patriarchal bargain" by opting the opting the identity of legal "Man" to take benefits and material advantages related with the identity of legal "Man" in a socio-legal system of patriarchy then the symbolic advantage srelated with the identity of legal transgender. So, in order to increase our comprehension of the legal consciousness of gender deviants, the finding of present study warns opposite to the 
construction of the legal transgender identity as a breakthrough or encouraging step for the inclusion of gender deviants. This study also confused the hypothesis that gender deviants would easily or without discrimination select the identity of legal transgender for of its symbolic benefits. The results of the present study also reveals that if the identity of legal transgender is to become a practical choice for social inclusion of gender deviants, states, particularly in third world nations, must provide the material advantages or benefits e.g. better employment chances, devoted welfare plans and policies to analyze the social costs that persons have to tolerate by opting the legal transgender identity. 


\section{References}

Baig, Rabail, (2012). A first for Pakistan's third gender. Foreign Policy, 30 March.

Baumle, Amanda K. \& D'Lane R. Compton, (2015). Legalizing LGBT families: How the lawshapes parenthood. New York: New York University Press.

Bochenek, Michael and Kyle Knight, (2012). Establishing a third gender category in Nepal: Process and prognosis. Emory International Law Review 26: 11-61.

Brettell, C. B., \& Sargent, C. F. (1997). Neither man nor woman. Gender in cross- cultural perspective (pp. 198-201). New Jersey: Prentice Hall.

Butler, Judith, (2004). Undoing gender. New York: Routledge.

Connolly, Catherine, (2002). The voice of the petitioner: The experiences of gay and lesbianparents in successful second-parent adoption proceedings. Law E Society Review 36:325-46.

Custer, Lindsay, (2016). Undoing gender: Making the invisible visible. In Teaching gender andsex in contemporary America, edited by Kristin Haltinner and Ryanne Pilgeram.Switzerland: Springer International Publishing.

Dufner, Martina, (2015). Intersex challenging a legal system based on binary gender. Master's Thesis, University of Geneva, Geneva, Switzerland.

Ewick, Patricia \& Susan S. Silbey, (1998). The common place of law: Stories from everyday life. Chicago: The University of Chicago Press.

Fraser, Nancy, (2000). Rethinking recognition. New Left Review 3(May-June): 107-20.

Fraser, Nancy, ( 2001). Recognition without ethics? Theory, culture and society 18(2-3): $21-42$.

Hall, Kira, (1995). Hijra/Hijrin: Language and gender identity. Ph. D diss., University of California Berkeley, Berkeley, CA.

Harding, Rosie, (2006). Dogs are "registered," people shouldn't be: Legal consciousness and lesbian and gay rights. Social $\mathcal{E}$ Legal Studies 15: 511-33.

Harding, Rosie, (2011). Regulating sexuality: Legal consciousness in lesbian and gay lives. Abingdon, UK: Routledge.

Hull, Kathleen E. (2003). The cultural power of law and the cultural enactment of legality: The case of same-sex marriage. Law $\mathcal{E}$ Social Inquiry 28: 629-57. 
Hull, Kathleen E. (2016). Legal consciousness in marginalized groups: The case of LGBT people. Law \& Social Inquiry 41(3): 551-72.

Inoguchi, Takashi \& Jean Blondel, (2010). Citizens and the state: Attitudes in western Europe and East and Southeast Asia. London: Routledge.

Kandiyoti, Deniz, (1988). Bargaining with patriarchy. Gender $\mathcal{E}$ Society 2(3): 274-90.

Khan, Mohammad Asif, (2007). Changes in the socio-economic structures in rural NorthWestPakistan. Kiel, Germany: Wiss-Vauk Kiel KG.

Knight, Kyle G., Andrew R. Flores, \& Sheila J. Nezhad, (2015). Surveying Nepal's thirdgender: Development, implementation, and analysis. Transgender Studies Quarterly2(1): 101-22.

Korteweg, Anna C. (2006). The construction of gendered citizenship at the welfare office: Anethnographic comparison of welfare-to-work workshops in the United States and the Netherlands. Social Politics: International Studies in Gender, State E Society 13(3): 314- 40.

Kuckartz, Udo, (2014). Qualitative text analysis: A guide to methods, practice and using software. Los Angeles, CA: Sage.

Levy, Robert I. \& Douglas W. Hollan, (2014). Person-centered interviewing and observation. In Handbook of methods in cultural anthropology, edited by Harvey Russell Bernard. Lanham, MD: Alta Mira Press.

Moffitt, Robert, 1983. An economic model of welfare stigma. The American Economic Review 73(5): 1023-35.

Molyneux, Maxine, (1985). Mobilization without emancipation? Women's interests, the state, and revolution in Nicaragua. Feminist studies 11(2): 227-54.

Monro, Surya, (2005). Gender politics. London: Pluto Press.

Moynihan, Donald, Pamela Herd, \& Hope Harvey, (2014). Administrative burden: Learning,psychological, and compliance costs in citizen-state interactions. Journal of Public Administration Research and Theory 25(1): 43-69.

Rao, Hamza, (2016). Saudi Arabia bans transgenders from Umrah pilgrimage. Daily Pakistan, 22 November.

Richman, Kimberly D. (2014). License to wed: What legal marriage means to same-sex couples. New York: New York University Press.

Salamon, Gayle, (2010). Assuming a body: Transgender and rhetorics of materiality. New York: Columbia University Press. 
Schilt, Kristen \& Laurel Westbrook, (2009). Doing gender, doing heteronormativity: "Gender normals," transgender people, and the social maintenance of heterosexuality. Gender \& Society 23(4): 440-64.

Sen, Amartya, (1992). Missing women. BMJ: British Medical Journal 304(6827): 587

Sharma, S. K. (2000). Hijras: The labelled deviance. New Delhi: Gyan Publishing House.

Silbey, Susan S. (2001). Legal culture and consciousness. In International encyclopedia of thesocial and behavioral sciences, edited by Neil J. Smelser and Paul B. Baltes.Amsterdam: Elsevier Science.

Silbey, Susan S. (2005). After legal consciousness. Annual Review of Law and Social Science. 1(1): 323-68.

Spade, Dean, (2008). Documenting gender. Hastings Law Journal 59(1): 731-841.

Stewart, S. Mahtani, Michael H. Bond, Wai Chan, Riffat M. Zaman, Rabiya Dar, \& Muhammad Anwar, (2003). Autonomy from parents and psychological adjustment in an interdependent culture. Psychology \& Developing Societies 15(1): $31-49$.

Stryker, Susan, (2004). Transgender studies: Queer theory's evil twin. GLQ: A Journal of Lesbian and Gay Studies 10(2): 212-15.

Singer, T. Benjamin, (2015). The profusion of things: The "transgender matrix" and demographic imaginaries in US public health. TSQ: Transgender Studies Quarterly 2(1): 58-76.

Stuber, Jennifer \& Mark Schlesinger, (2006). Sources of stigma for means-tested government programs. Social Science \& Medicine 63(4): 933-45.

Walby, Sylvia, (1991). Theorizing patriarchy. Oxford, UK: Blackwell.

Westbrook, Laurel \& Kristen Schilt, (2014). Doing gender, determining gender: Transgenderpeople, gender panics, and the maintenance of the sex/gender/sexuality system. Gender\& Society 28(1): 32-57.

Yanow, Dvora, (2003). Constructing "race" and "ethnicity" in America: Category-making inpublic policy and administration. Armonk, NY: M.E. Sharpe. 